\title{
Behavioral Evaluation of Male and Female Carioca High- and Low-Freezing Rats
}

\author{
Marcelo Salviano \\ Departamento de Psicologia da Universidade de Brasília, Brasília, Distrito Federal, Brasil \\ Graziela Ferreira \\ Departamento de Psicologia da Universidade de Brasília, Brasília, Distrito Federal, Brasil \\ Departamento de Psicologia da Pontifícia Universidade Católica de Brasília, Brasília, \\ Distrito Federal, Brasil \\ Marília Greidinger \\ Departamento de Psicologia da Universidade de Brasillia, Brasília, Distrito Federal, Brasil \\ Departamento de Psicologia do Instituto de Educação Superior de Brasília, Brasília, \\ Distrito Federal, Brasil \\ Kaliu Couto \\ Departamento de Psicologia do Instituto de Educação Superior de Brasília, Brasília, \\ Distrito Federal, Brasil

\section{J. Landeira-Fernandez ${ }^{1}$} \\ Departamento de Psicologia da Pontifícia Universidade Católica do Rio de Janeiro, \\ Rio de Janeiro, Rio de Janeiro, Brasil
}

A. Pedro de Mello Cruz

Departamento de Psicologia da Universidade de Brasília, Brasília, Distrito Federal, Brasil

\begin{abstract}
Recent years have seen growing interest in the development of genetic animal models to investigate the bidirectional relationship between trait anxiety and defensive reactions. The present study further analyzed behavioral correlates of two novel breeding lines of rats, Carioca high-and low-conditioned freezing (CHF and CLF), based on defensive freezing responses to contextual cues previously associated with electric footshock. Male and female rats from the 10th generation were used to assess anxiety-like reactions in the elevated plus maze (EPM), depressive-like behavior in the forced swim test (FST), and aversive memory in the contextual fear conditioning paradigm. In the EPM, female rats showed lower anxiety-like behavior than males, whereas CHF rats were more anxious than CLF rats. The same pattern of results was found in the contextual fear conditioning paradigm. No differences were found between lines or sexes in the FST. Such differences in emotionality responses in the 10th generation of selected rats further indicate a possible use of this model to study correlations between trait anxiety and defensive reactions. The face validity of the model and its use to experimentally simulate generalized anxiety disorder in humans are also discussed.
\end{abstract}

Keywords: Genetic animal model, contextual fear conditioning, anxiety.

1 Mailing address: Departamento de Psicologia, Pontifícia Universidade Católica do Rio de Janeiro, Rua Marquês de São Vicente, 225, Rio de Janeiro, RJ, Brasil 22453-900. E-mail: landeira@puc-rio.br 


\section{Avaliação Comportamental de Ratos Machos e Fêmeas Cariocas Alto e Baixo Congelamento}

\section{Resumo}

Nos últimos anos, tem crescido o interesse pelo desenvolvimento de modelos animais geneticamente modificados para o estudo da relação bidirecional entre ansiedade traço e reações de defesa. O presente estudo analisou a correlação comportamental de duas novas linhagens de ratos, denominados de Carioca Alto e Baixo Congelamento (CHF e CLF), baseado na resposta de congelamento a estímulos contextuais previamente associados a choque elétrico nas patas. Foram utilizados ratos machos e fêmeas da $10^{\mathrm{a}}$ geração para serem avaliadas as reações relacionadas à ansiedade no labirinto em cruz elevado (LCE), comportamentos relacionados à depressão no teste do nado forçado (TNF) e a memória aversiva no paradigma do medo condicionado ao contexto. No LCE, ratas fêmeas apresentaram um menor índice de comportamento indicativo de ansiedade comparadas aos machos. Mais ainda, animais da linhagem CHF apresentaram maiores índices de ansiedade em relação a animais da linhagem CLF. O mesmo padrão de resultados foi encontrado no paradigma do medo condicionado ao contexto. Não foram encontradas diferenças entre as linhagens ou entre os sexos testados no TNF. Tais diferenças nas respostas emocionais da $10^{a}$ geração de ratos geneticamente selecionados indicam uma possível utilização deste modelo no estudo de correlações entre ansiedade traço e reações de defesa. A validade de face do modelo e seu uso para simular experimentalmente o transtorno da ansiedade generalizada em humanos também são discutidos.

Palavras-chave: Modelos animais geneticamente modificados, medo condicionado ao contexto, ansiedade.

\section{Evaluación Comportamental em Ratas Machos y Hembras Cariocas Alto y Bajo Congelamineto}

\section{Resumen}

En los ultimos años, ha crescido el interés por el desarrollo de modelos animales geneticamente modificados para el estudio de la relación bidireccional entre ansiedad de rasgo y reaciones de defensa. El presente estudio analisó la correlación existente en el comportamiento de dos nuevas linajes de ratones, denominados de Carioca Alto y Bajo Congelamiento (CHF e CLF), basado en la respuesta de congelamiento a estimulos contextuales previamente asociados a choque elétrico en las patas. Fueron utilizados ratones machos y hembras de la $10^{\mathrm{a}}$ generación para que fuesen evaluadas las reacciones relacionadas a la ansiedad en el laberinto en cruz elevado (LCE), comportamientos relacionados a la depresión en el teste de natación forzada (TNF) y la memória aversiva en el paradigma del miedo condicionado al contexto. En el LCE, las ratazanas presentaron un menor índice de comportamiento indicativo de ansiedad, se comparadas a los ratones machos. Animales de la linaje CHF presentaran mayores índices de ansiedad que los animales de la linaje hembras CLF. El mismo patrón de resultados fue encontrado em el paradigma del miedo condicionado al contexto. No se encontraron diferencias entre los linajes ó entre los sexos testados en el TNF. Tales diferencias en las respuestas emocionales de la $10^{\mathrm{a}}$ generación de ratones geneticamente selecionados indican una posible utilización de ese modelo en el estudio de correlación entre ansiedade de rasgo y reacciones de defensa. La validad de contenido yaparente del modelo y sus utilización para simular experimentalmente el transtorno de la ansiedad generalizada en humanos, también son discutidos.

Palabras clave: Modelos animales modificados genéticamente, miedo condicionado al contexto, ansiedad. 
Genetic models have been widely used to study animal behavior and investigate the influence of genetic factors on a variety of behavioral traits and possible emotionality disorders (Cryan \& Holmes, 2005; Wegener, Mathé, \& Neumann, 2012). Selective breeding has been shown to be a reliable technique to correlate a behavioral trait with related genes. A large number of new rat and mouse lines have been developed by selecting many different phenotypes, such as high and low levels of defecation (Blizard \& Adams, 2002), ultrasonic vocalization (Brunelli \& Hofer, 1996), hypertension (Hendley, Atwater, Myers, \& Whitehorn, 1983), resistance to immobility (Weiss, Cierpial, \& West, 1998), emotional behaviors and learning processes (Liebsch, Montkowski, Holsboer, \& Landgraf, 1998; Ponder et al., 2007; Ramos, Correia, Izidio, \& Bruske, 2003).

When developing a genetic model by selectively breeding a particular behavior, identifying whether other behaviors are also selected is important. Once the behavioral differences caused by genetic selection are identified, whether the selected trait is in fact responsible for the selected phenotype should be determined because genes can be responsible for two or more different traits. For example, strains of spontaneously hypertensive rats (SHRs) have high blood pressure, but they also show more activity than Wistar Kyoto strain when exposed to both familiar and novel environments (Hendley et al., 1983). Hendley and Ohlsson (1991) later showed that these traits were independently dissociable, in which they were able to produce two new strains from the SHR strains: hypertensive normoactive (WKHT) and normotensive hyperactive (WKHA).

The use of rodent genetic models has been useful for understanding the correlation between a genetic predisposition to trait anxiety and learned fear and developing new ways to elucidate neurologic pathways and related genes (Sartori, Landgraf, \& Singewald, 2011; Steckler, Stein, \& Holmes, 2008). Brigman, Mathura, Lu, Williams, and Holmes (2009) performed a factor analysis and compared several inbred mouse strains with regard to various trait measures of fear conditioning and anxiety-like behavior.
These authors found a coloading of contextual fear with anxiety-like behavior on the elevated plus maze (EPM) within the same factor, which indicates that both tests are analyzing the same behavioral response. This might explain the fact that the use of contextual fear conditioning has been a reliable behavioral test to select animals with different anxiety profiles and develop new genetic models based on different emotionality phenotypes (Ponder et al., 2007; Radcliffe, Lowe, \& Wehner, 2000; Wehner et al., 1997).

The present study used a genetic model of rats previously developed by V. C. Gomes and Landeira-Fernandez (2008), in which two new lines of Wistar rats were selectively bred for high and low levels of freezing in response to contextual cues previously associated with footshock, termed Carioca High- and Low-Freezing (CHF and CLF, respectively). Given the potential of this model as a tool for studying the development of anxiety disorders, the main objective of the present study was to analyze two different generations of selected rats in two other emotionality tests, the EPM and forced swim test (FST), and test the aversive memory in the contextual fear conditioning paradigm.

\section{Methods}

\section{Animals}

All of the animals were obtained according to procedures previously described by V. C. Gomes and Landeira-Fernandez (2008). Wistar rats were selectively bred for differences in freezing behavior in a contextual fear conditioning test, in which the rats with the highest contextual freezing scores were selected to breed the CHF line while avoiding brothersister breeder pairs. The rats with the lowest freezing levels were used to breed the CLF line. In the present study, CHF and CLF rats from the 10th generation were used to analyze anxietylike behavior in the EPM, depressive-like behavior in the FST, and aversive memory in the contextual fear conditioning paradigm. The experimenters remained blind to the rat lines throughout testing. The experimental procedures reported herein were performed based on the 
guidelines for the use of animals in experimental research established by the Brazilian Society of Neuroscience and Behavior (SBNeC) and were in accordance with the National Institutes of Health Guide for the Care and Use of Laboratory Animals. Animal handling and sacrifice methods were reviewed and approved by the Committee for Animal Care and Use of the Biology Institute/ University of Brasilia (UnB).

\section{Experimental Procedure}

Ninth-generation rats were received in our laboratory from Pontificia Universidade Católica do Rio de Janeiro (PUC-Rio) and then bred according to V. C. Gomes and Landeira-Fernan$\operatorname{dez}$ (2008). The pups from this generation, labeled as S10 rats, were used in the present study. We tested eight males and eight females of the CHF line and six males and eight females of the CLF line. The rats were tested at 2-3 months of age and weighed 190-330 g. The animals were housed in acrylic cages $(31 \mathrm{~cm} \times 38 \mathrm{~cm})$ in groups of 3-5 in an animal room under a 12 $\mathrm{h} / 12 \mathrm{~h}$ light/dark cycle (lights on at 8:00 AM) with food and water provided ad libitum. All of the experiments were conducted between 2:006:00 PM during the light phase of the light/dark cycle. The animals were brought to the testing room in their home cages and allowed to adapt for $30 \mathrm{~min}$ before testing. Each day of experiment used animal from all groups, such as males, females, CLF and CHF. All of the S10 animals were tested in the EPM, FST, and contextual fear conditioning paradigm, in this order and with a $24 \mathrm{~h}$ interval between the EPM and FST and 40 day interval between the FST and fear conditioning test. The long period between FST and fear conditioning test was done to avoid behavioral influence, as the FST is highly aversive (Blokland et al., 2012). The animals' behavior in the three apparatus were videotaped for behavioral scoring at a later time by a blinded and highly experienced observer.

\section{Elevated Plus Maze}

The apparatus was made of wood and consisted of two open arms $(50 \times 10 \mathrm{~cm})$ and two perpendicular closed arms $(50 \times 10 \times 40 \mathrm{~cm})$ connected by a central area $(10 \times 10 \mathrm{~cm})$. The EPM was elevated $50 \mathrm{~cm}$ from the floor, surrounded by $1 \mathrm{~cm}$ high Plexiglas $(1 \mathrm{~cm}$ high) in the perimeter of the open arms to minimize falling from the arms (Pellow, Johnston, \& File, 1987). All of the animals were handled for $2 \mathrm{~min}$ on 5 consecutive days prior to the experimental sessions to habituate them to the stresses to which they are commonly subjected immediately before plusmaze testing (i.e., experimenter manipulation, removal from home cage; Lapin, 1995). Each rat was placed in the central area facing a closed arm and allowed to freely explore the maze for $5 \mathrm{~min}$. The maze was cleaned with a solution of $20 \%$ ethanol and dried between subjects. The experimental session was illuminated by a bright light and recorded by a camera located $175 \mathrm{~cm}$ above the maze. The behavioral measures were later analyzed according to the protocol described by Cruz, Frei, and Graeff (1994). For each animal, the frequency and duration of exploration in the open- and closed-arms, were recorded.

\section{Forced Swim Test}

The rat FST apparatus was based on the specifications described by Porsolt, Bertin, and Jalfre (1978) and Porsolt, Le Pichon, and Jalfre (1977) with some adaptations. Briefly, it consisted of a transparent cylinder (46 cm height ' $20 \mathrm{~cm}$ diameter) that was filled with water $(26 \pm$ $2{ }^{\circ} \mathrm{C}$ ) to a depth of $30 \mathrm{~cm}$. The rats were placed in the cylinder and forced to swim without the opportunity to escape (F. Gomes et al., 2010). They remained in the water until immobility developed, which was defined as the cessation of limb movements except those necessary to keep the animal afloat. The rats were tested in the FST with two exposures to the water tank spaced 24 $\mathrm{h}$ apart (trial session and test session, respectively). The first trial lasted $15 \mathrm{~min}$, and the second trial was $5 \mathrm{~min}$. Only the second trial was recorded, and the duration of immobility and latency to exhibit immobility were analyzed. After swimming, each animal was gently dried with a towel and a hair blow dryer. The water in the tank was changed between rats. 


\section{Contextual Fear Conditioning}

The fear conditioning chamber $(25 \times 20 \mathrm{x}$ $20 \mathrm{~cm}$ ) had metal walls on each side, clear plastic front and back walls and ceilings, and stainless steel bars on the floor. The chamber was placed inside a sound-attenuating chest that had dim illumination. A fan provided a low level of masking background noise. The apparatus was cleaned between animals with $20 \%$ ethanol and diluted lime scent. The use of odor cue has been shown as a useful method to enhance the animal context association (Rudy, Huff, \& Matus-Amat, 2004). Behavior was recorded with a digital video camera and analyzed by a well-trained observer. A time-sampling procedure was used to evaluate fear conditioning to contextual cues, in which episodes of freezing were recorded every $2 \mathrm{~s}$. Freezing was defined as the total absence of movement of the body or vibrissa, with the exception of movements required for respiration.

The contextual fear conditioning protocol was adapted from V. C. Gomes and LandeiraFernandez (2008) and involved acquisition and test trials. During acquisition, each animal was placed in the observation chamber for $4 \mathrm{~min}$. At the end of this period, three unsignaled electrical footshocks $(0.6 \mathrm{~mA})$ were delivered, with each shock lasting $1 \mathrm{~s}$ and an intershock interval of $20 \mathrm{~s}$. The animal was returned to its home cage 2 min after the last shock. The test trial occurred approximately $24 \mathrm{~h}$ after training. This test consisted of placing the animal in the same chamber as the acquisition trial for 8 min with no footshock or other stimulation during this period. Freezing behavior was recorded only in the test trial.

\section{Data Analysis}

Because males and females from the $\mathrm{S} 10$ line were tested, differences were analyzed using a two-way analysis of variance (ANOVA), with sex and line as factors. When ANOVA revealed reliable interaction between sex and line factors, the Duncan post-hoc tests was employed to identify statistical differences between groups. All of the analyses were performed us- ing StatView 5.0.1 software (SAS Institute, San Francisco, CA, USA).

\section{Results}

\section{Elevated Plus Maze}

Figure 1A presents the mean (SEM) of time spent in the open arm of the EPM. As it can be observed, female rats spent more time in the open arm when compared to male rats. Also, CLF rats also spent more time in the open arm when compared to CHF rats. This impression was confirmed by the two-way ANOVA which revealed no interaction between sex an line $(F 1,23=.43$; $p>.50)$ but a main effect of line $(F 1,23=8.78$; $p<.01)$ and $\operatorname{sex}(F 1,23=5.51 ; p<.05)$. Figure $1 \mathrm{~B}$ presents the mean (SEM) number of entries into the closed arms. The two-way ANOVA indicated an absence of interaction $(F 1,23=.30 ; p$ $>.50)$ as well as main effect of line $(F 1,23=.82$; $p>.37)$ and $\operatorname{sex}(F 1,23=2.79 ; p>.10)$.

\section{Forced Swim Test}

Figure 2 presents the mean (SEM) of percentage of time spent immobile (2A) and latency to immobility (2B) in the FST. As it can be observed, no differences among the groups are apparent. This impression was confirmed by the two-way ANOVA. No interaction $(F 1,26$ $=.01 ; p>.91)$ or main effects of line $(F 1,26$ $=.63 ; p>.81)$ and sex $(F 1,26=.08 ; p>.77)$ in the percentage of time spent immobile. No interaction $(F 1,26=.06 ; p>.79)$ or main effects of line $(F 1,26=.39 ; p>.53)$ and $\operatorname{sex}(F 1,26=$ $.01 ; p>.91)$ were also found in the latency to immobility.

\section{Contextual Fear Conditioning}

Figure 3 depicts the mean (SEM) of percentage of time spent in freezing during the contextual fear conditioning test. The two-way ANOVA indicated an absence of interaction $(F 1,26=.01$; $p>.91)$ but a main effect of line $(F 1,26=13.55$; $p<.001)$ and $\operatorname{sex}(F 1,26=11.99 ; p<.01)$. These analyses confirmed that male animals froze more than female rats and that $\mathrm{CHF}$ rats froze more than CLF animals. 
Figure 1. Mean (+ SEM) percent time spent in the open arms (A), and number of entries into the closed arms (B) in S10 male and female rats in the EPM.
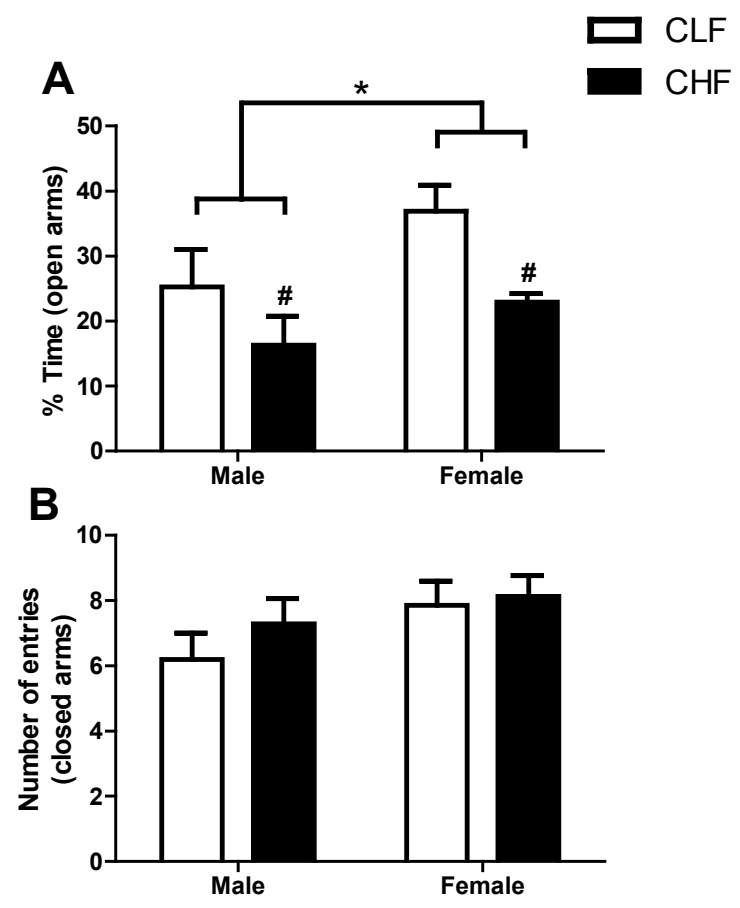

Note. Number of animals in male CLF group $=7$; male CHF group $=5$; female CLF group $=7$; female CHF group $=8$.

${ }^{*} p<.05$, sex effect; ${ }^{*} p<.01$, line effect.

Figure 2. Mean (+ SEM) percent time spent immobile (A) and latency to immobility (B) in the forced swim test in S10 male and female rats.

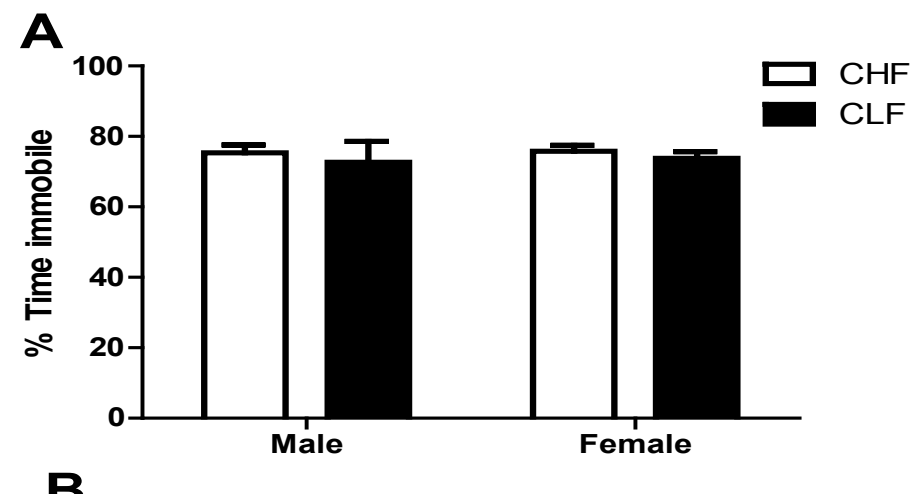

B

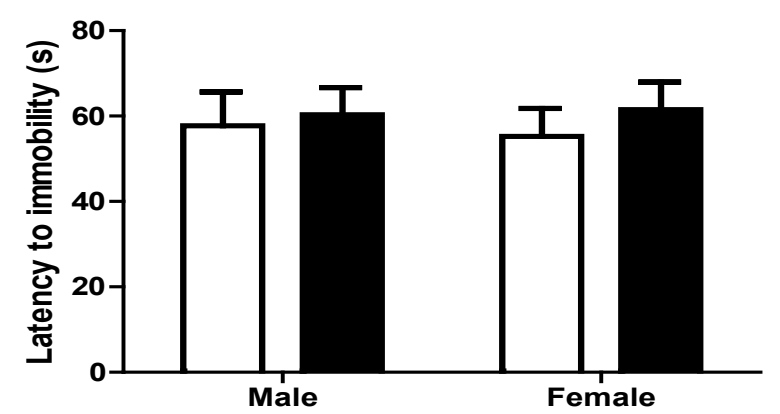

Note. Number of animals in male CLF group $=6$; male CHF group $=8$; female CLF group $=8$; female $\mathrm{CHF}$ group $=8$. 
Figure 3. Mean (+ SEM) of freezing percentage in S10 male and female rats on the second day of contextual fear conditioning.

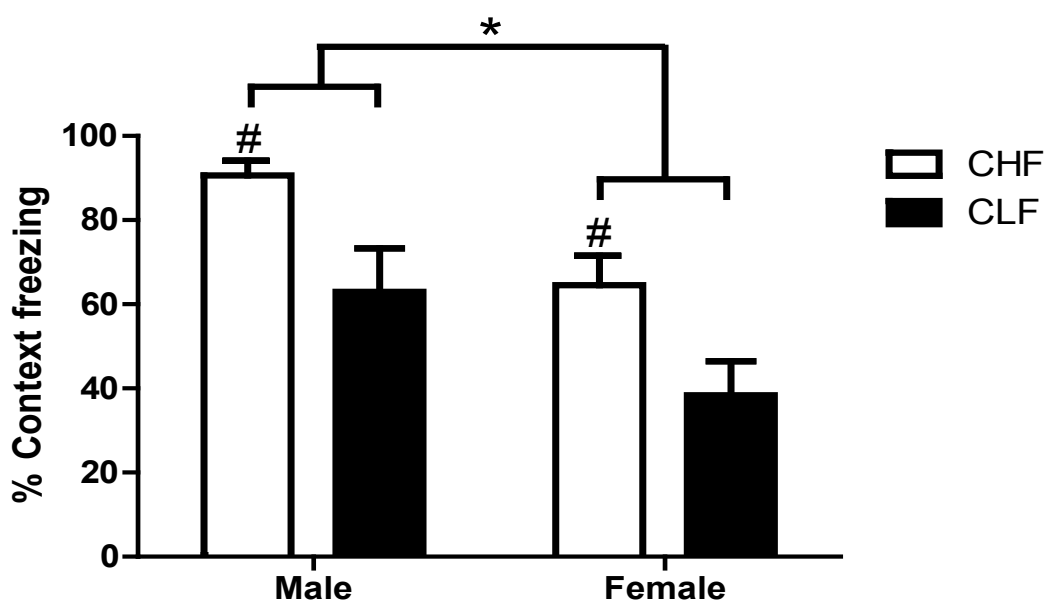

Note. Number of animals in male CLF group $=6$; male CHF group $=8$; female CLF group $=8$; female $\mathrm{CHF}$ group $=8$.

${ }^{*} p<.001$, sex effect; ${ }^{\#} p<.01$, line effect.

\section{Discussion}

The present study found that CHF rats spent less time in the open arms of the EPM when compared to CLF animals, a phenotype consistent with high anxiety-like behavior (Cruz et al., 1994; Ramos, Berton, Mormede, \& Chaouloff, 1997; Setem, Pinheiro, Motta, Morato, \& Cruz, 1999). Male rats also spent less time in the open arm of the EPM when compared to female rats. No difference was found between lines in closed arm entries on the EPM or time spent swimming in the FST. We propose that the higher level of anxiety-like behavior of the CHF rats is not attributable to differences in activity levels between the two lines (Cruz et al., 1994; Ramos, Mellerin, Mormède, \& Chaouloff, 1998). These data suggest that the CHF and CLF lines can be used as a model of trait anxiety because baseline levels of anxiety in these subjects were different from each other, without prior exposure to aversive stimuli. Unlike state anxiety, trait anxiety does not vary from moment to moment and is considered an enduring feature of an individual (Belzung \& Griebel, 2001).

It is possible that differences between the lines CHF and CLF were due to differences in activity level as the analyzed behaviors were dependent on locomotor activity (File, 2001).
However, factor analysis studies indicated that the number of entries in the closed arms are not an anxiety related behavior, but a motor activity related one (Cruz et al., 1994; Ramos et al., 1998). Although no motor activity evaluation was performed in the present study, we do not attribute the anxiety-like behavior differences to locomotion pattern since no differences were found on the number of entries in the closed arms of the EPM.

Genetic selection over ten generations of $\mathrm{CHF}$ and CLF rats showed similar results to studies of other CHF/CLF generations (Dias, Bevilaqua, Silveira, Landeira-Fernandez, \& Gardino, 2009; V. C. Gomes \& Landeira-Fernandez, 2008; V. C. Gomes, Silva, \& Landeira-Fernandez, 2011; Hassan, Gomes, Pinton, Rocha, \& Landeira-Fernandez, 2013) and are consistent with other studies that used contextual fear conditioning to selectively breed new reactive lines (Ponder et al., 2007; Radcliffe et al., 2000; Wehner et al., 1997). The animals used in the present study were selected for a fear-related response, paralleled anxiety-related behavior in the EPM was significantly different between the selected lines both in male and female rats.

A good animal model should sufficiently meet three criteria: face validity, predictive validity, and construct validity. Face validity refers 
to the phenomenological similarity between the behavior exhibited by the animal and specific symptoms of the human condition. Predictive validity indicates discrimination between effective and ineffective treatments. Construct validity is based on a robust theoretical rationale that refers to similarities in underlying mechanisms or etiology (Graeff \& Zangrossi, 2002). The development of selected lines of rats with higher or lower contextual conditioned fear appears to be a useful way to study "psychopathological" animals with abnormal (e.g., elevated or lowered) anxiety because they provide face validity for generalized anxiety disorder (GAD). The symptoms presented by patients with GAD include muscle tension (according to the Diagnostic and Statistical Manual of Mental Disorders, $4^{\text {th }}$ edition) and the inhibition of motor behavior and mental freezing (American Psychiatric Association, 2000; de Beurs et al., 1999; Golbin, Kravitz, \& Keith, 2004; Gorwood, 2004; Lyonfields, Borkovec, \& Thayer, 1995), which can be correlated with freezing behavior exhibited by rodents subjected to contextual fear conditioning (Antoniadis \& McDonald, 1999; Luyten, Vansteenwegen, van Kuyck, Gabriëls, \& Nuttin, 2011; Phillips \& LeDoux, 1994). A model of GAD should be able to show diffuse, unfocused, or "generalized" anxiety in response to a nonspecific stimulus over time (Luyten et al., 2011). The model proposed in the present study offers face validity because the anxietylike behavior exhibited by the animals was selected rather than induced.

In the present study, we found that males froze more than females in both the CHF and CLF lines, which was previously found by $\mathrm{V}$. C. Gomes and Landeira (2008) who tested the first three generations. In animal models, males consistently outperform females in studies of inhibitory avoidance, showing higher latencies to reenter a chamber previously associated with shock (Drago, Bohus, Scapagnini, \& de Wied, 1980; Heinsbroek, van Oyen, \& van de Poll, 1984; Kudo, Qiao, Kanba, \& Arita, 2004) or more prolonged freezing, regardless of whether the shock is signaled by a context (Barker \& Galea, 2010; Gupta, Sen, Diepenhorst, Rudick,
\& Maren, 2001; Maren, De Oca, \& Fanselow, 1994; Wiltgen, Sanders, Behne, \& Fanselow, 2001) or discrete conditioned stimulus (Pryce, Lehmann, \& Feldon, 1999). Some studies have shown that estrogen is involved in the impaired freezing in the contextual fear conditioning response in female rats (Gupta et al., 2001).

We also found sex differences in the EPM, although many studies did not report sex differences in anxiety (Bridges \& Starkey, 2004; Marcondes, Miguel, Melo, \& Spadari-Bratfisch, 2001; Rauch, Shin, \& Phelps, 2006; Rodgers \& Cole, 1993; Stock, Foradori, Ford, \& Wilson, 2000). However, rats that have been previously exposed to inescapable shock and tested in the EPM showed significant sex differences, with males showing higher levels of behavior that is indicative of anxiety, similar to the present results (Steenbergen, Heinsbroek, Van Hest, \& Van de Poll, 1990). These findings suggest that differences in the fear conditioning response that have been selected over many generations appear to sex-dependently influence emotional systems in both the CHF and CLF lines. It is important to note that several studies showed the influence of the estrous cycle on rodents' behavior (Johnston \& File, 1991; Marcondes et al., 2001). Basal anxiety levels can vary within the phase of the cycle. For example, Diaz-Veliz, Alarcon, Espinoza, Dussaubat, and Mora (1997) repsoted a significant increase in the time spent as well as in the percentage of entries into the open arms during proestrus and estrus compared to diestrus and metestrus. However, Nomikos and Spyraki (1988) shows no significant difference between proestrus and diestrus. The present study did not analyzed the estrus cycle on female rats. Indedd, more studies are necessary to fully understand the possible interaction between estrous cycle with female CHF and CLF animal

The contextual fear conditioning paradigm has been often used to study mnemonic processes and measure aversive memory (for review, see Rudy et al., 2004). This test is undeniably dependent on mnemonic processes, but recent studies have shown the influence of anxiety on contextual fear conditioning behavior (Ponder et al., 2007; Sartori, Hauschild, et al., 2011; Silva 
\& Frussa-Filho, 2000; Silva et al., 2002). A study that used the sixth generation of the CHF line reported no cognitive differences in the novel object recognition test compared with a control group of Wistar rats (Dias et al., 2009). Therefore, the breeding method used for the CHF/ CLF genetic model selected animals according to their anxiety rather than cognitive capabilities. However, other cognitive tests, such as the Morris water maze and radial arm maze, should be performed to validate this further.

Selective breeding for high anxiety-related behavior in the EPM also results in increased freezing in the contextual fear conditioning paradigm in mice (Sartori, Hauschild, et al., 2011). Sokoloff, Parker, Lim, and Palmer (2011) performed a factor analysis to study anxiety and fear in the open field and fear conditioning tests and identified multiple quantitative trait loci (QTL) for anxiety-like behavior measured in these tests. These studies demonstrated some portion of shared genetic architecture between anxietyand fear-related behaviors.

Anxiety is represented by complex traits that have been studied in several animal models, and some researchers have reported comorbidity of anxiety and depression (Cryan \& Holmes, 2005; Merikangas et al., 2003; Wegener et al., 2012). Landgraf and Wigger (2002) showed that animals with high anxiety exhibit more passive and depression-like behavior when exposed to a stress coping situation. Studies have shown the efficacy of pharmacological treatments for both types of disorders (Carr, Schechter, \& Lucki, 2011; Holmes, Heilig, Rupniak, Steckler, \& Griebel, 2003; Nikiforuk, Kos, \& Wesołowska, 2011). However, none of these studies investigated trait differences or genetic factors. We found no difference in depression-like behavior in the FST. A previous study that used the fourth generation of the CHF line also found no difference in the FST (Dias et al., 2009). The absence of a correlation between anxiety and depression was also found in a genetic model of depression developed by selectively breeding the Flinders Sensitive Line (FSL) for sensitivity to irreversible anticholinesterase agents. This new line exhibited significantly increased immobility in the FST that was reversible with chronic antidepressant drug treatment compared with the Flinders Resistant Line (FRL; El Khoury, Gruber, Mork, \& Mathe, 2006; Overstreet \& Russell, 1982; Schiller, Pucilowski, Wienicke, \& Overstreet, 1992). Under baseline conditions, no differences were discovered between the FSL and FRL lines (Overstreet, Pucilowski, Rezvani, \& Janowsky, 1995), and benzodiazepine treatment exerted a comparable anxiolytic effect in both FSL and FRL rats, with no difference between the two lines (Schiller, Daws, Overstreet, \& Orbach, 1991).

In conclusion, the present results, together with other published data on the CHF/CLF rat lines (Dias et al., 2009; Galvão, Gomes, Maisonnette, \& Landeira-Fernandez, 2011; V. C. Gomes \& Landeira-Fernandez, 2008; V. C. Gomes et al., 2011; León, Brandão, Franci, Cardenas, \& Landeira-Fernandez, 2013), sugests a possible use of rats with high and low levels of contextual fear conditioning as a model of GAD. Our results support the purported link between contextual fear conditioning and anxiety, with rats selected for high contextual fear conditioning showing high anxiety-like behavior, particularly in females. The present study analyzed sex differences in anxiety-like behavior in the CHF/ CLF lines, and we found lower anxiety-like and fear conditioned behavior in females compared with males. This was the first time that a comparison between sex is made with this new line of rats. The use of selected anxious rat strains that show consistently high levels of fearfulness may provide models of anxiety that have greater face, construct, or predictive validity than state or single-gene deletion models of anxiety. It is still soon to assume that the present results are enough to validate a model of an anxiety disorder, so more studies are needed, especially with regard to construct and predictive validity.

\section{References}

American Psychiatric Association. (2000). Diagnostic and statistical manual of mental disorders ( $4^{\text {th }}$ ed., Rev. Ed.). Washington, DC: Author.

Antoniadis, E. A., \& McDonald, R. J. (1999). Discriminative fear conditioning to context expressed by multiple measures of fear in the rat. Behavioural Brain Research, 101(1), 1-13. 
Barker, J. M., \& Galea, L. A. M. (2010). Males show stronger contextual fear conditioning than females after context pre-exposure. Physiology and Behavior, 99(1), 82-90. doi:10.1016/j.physbeh.2009.10.014

Belzung, C., \& Griebel, G. (2001). Measuring normal and pathological anxiety-like behaviour in mice: A review. Behavioural Brain Research, 125(1-2), 141-149. doi:10.1016/S01664328(01)00291-1

Blizard, D. A., \& Adams, N. (2002). The Maudsley Reactive and Nonreactive strains: A new perspective. Behavior Genetics, 32(5), 277-299.

Blokland, A., Ten Oever, S., van Gorp, D., van Draanen, M., Schmidt, T., Nguyen, E., ... Klinkenberg, I. (2012). The use of a test battery assessing affective behavior in rats: Order effects. Behavioural Brain Research, 228(1), 1621. doi:10.1016/j.bbr.2011.11.042

Bridges, N. J., \& Starkey, N. J. (2004). Sex differences in Mongolian gerbils in four tests of anxiety. Physiology and Behavior, 83, 119-127. doi:10.1016/j.physbeh.2004.08.002

Brigman, J. L., Mathura, P., Lu, L., Williams, R. W., \& Holmes, A. (2009). Genetic relationship between anxiety-related and fear-related behaviors in BXD recombinant inbred mice. Behavioural Pharmacology, 20(2), 204-209. doi:10.1097/ FBP.0b013e32830c368c

Brunelli, S. A., \& Hofer, M. A. (1996). Development of ultrasonic vocalization responses in genetically heterogeneous National Institutes of Health (N:NIH) rats: II. Associations among variables and behaviors. Developmental Psychobiology, 29(6), 517-528. doi:10.1002/ (SICI)1098-2302(199609)29:6<517::AIDDEV4>3.0.CO;2-P

Carr, G. V., Schechter, L. E., \& Lucki, I. (2011). Antidepressant and anxiolytic effects of selective 5- $\mathrm{HT}_{6}$ receptor agonists in rats. Psychopharmacology (Berl), 213, 499-507. doi:10.1007/ s00213-010-1798-7

Cruz, A. P. M., Frei, F., \& Graeff, F. G. (1994). Ethopharmacological analysis of rat behavior on the elevated plus-maze. Pharmacology Biochemestry and Behavior, 49, 171-176. doi:10.1016/0091-3057(94)90472-3

Cryan, L. F., \& Holmes, A. (2005). The ascent of mouse: Advances in modelling human depression and anxiety. Nature Reviews Drug Discovery, 4(9), 775-790. de Beurs, E., Beekman, A. T., van Balkom, A. J., Deeg, D. J., van Dyck, R., \& van Tilburg, W. (1999). Consequences of anxiety in older persons: Its effect on disability, well-being and use of health services. Psychological Medicine, 29, 583-593.

Dias, G. P., Bevilaqua, M. C., Silveira, A. C., Landeira-Fernandez, J., \& Gardino, P. F. (2009). Behavioral profile and dorsal hippocampal cells in Carioca high-conditioned freezing rats. Behavioural Brain Research, 205(2), 342-348. doi:10.1016/j.bbr.2009.06.038

Diaz-Veliz, G., Alarcon, T., Espinoza, C., Dussaubat, N., \& Mora, S. (1997). Ketanserin and anxiety levels: Influence of gender, estrous cycle, ovariectomy and ovarian hormones in female rats. Pharmacology Biochemistry and Behavior, 58(3), 637-642. doi:10.1016/S00913057(97)90004-6

Drago, F., Bohus, B., Scapagnini, U., \& de Wied, D. (1980). Sexual dimorphism in passive avoidance behavior of rats: Relation to body weight, age, shock intensity and retention interval. Physiology and Behavior, 24, 1161-1164.

El Khoury, A., Gruber, S. H., Mork, A., \& Mathe, A. A. (2006). Adult life behavioral Consequences of early maternal separation are alleviated by escitalopram treatment in a rat model of depression. Progress in Neuropsychopharmacology and Biological Psychiatry, 30(3), 535-540.

File, S. (2001). Factors controlling measures of anxiety and responses to novelty in the mouse. Behavioural Brain Research, 125, 151-157.

Galvão, B. O., Gomes, V. C., Maisonnette, S., \& Landeira-Fernandez, J. (2011). Panic-like behaviors in Carioca high-and low-conditioned freezing rats. Psychology \& Neuroscience, 4(2), 205-210. doi:10.3922/j.psns.2011.2.005

Golbin, A. Z., Kravitz, H. M., \& Keith, L. G. (Eds.). (2004). Sleep psychiatry. London: Taylor and Francis.

Gomes, F., Greidinger, M., Salviano, M. F., Couto, K. C., Scaperlli, G. F., Alves, S. H. S., \& Cruz, A. P. M. (2010). Antidepressant- and anxiogeniclike effects of acute 5-HT2C receptor activation in rats exposed to the forced swim test and elevated plus maze. Psychology \& Neuroscience, 3, 245-249. doi:http://dx.doi.org/10.3922/j. psns.2010.2.014

Gomes, V. C., \& Landeira-Fernandez, J. (2008). Amygdaloid lesions produced similar contex- 
tual fear conditioning disruption in the Carioca high- and low-conditioned freezing rats. Brain Research, 1233, 137-145. doi:10.1016/j. brainres.2008.07.044

Gomes, V. C., Silva, C. E. B., \& Landeira-Fernandez, J. (2011). The Carioca high and low conditioned freezing lines: A new animal model of generalized anxiety disorder. In V. V. Kalinin (Ed.), Anxiety disorders (pp. 121-134). Rijeka, Croatia: InTech.

Gorwood, P. (2004). Generalized anxiety disorder and major depressive disorder comorbidity: An example of genetic pleiotropy? European Psychiatry, 19(1), 27-33. doi:10.1016/j.eurpsy.2003.10.002

Graeff, F. G., \& Zangrossi, H. (2002). Animal models of anxiety disorders. In H. D'Haenen, J. A. den Boer, \& P. Willner (Eds.), Biological psychiatry (pp. 879-893). Chichester, UK: Wiley.

Gupta, R. R., Sen, S., Diepenhorst, L. L., Rudick, C. N., \& Maren, S. (2001). Estrogen modulates sexually dimorphic contextual fear conditioning and hippocampal long-term potentiation (LTP) in rats. Brain Research, 888(2), 356-365. doi:10.1016/S0006-8993(00)03116-4

Hassan, W., Gomes, V. C., Pinton, S., Rocha, J. B. T., \& Landeira-Fernandez, J. (2013). Association between oxidative stress and contextual fear conditioning in Carioca high- and low-conditioned freezing rats. Brain Research, 1512, 6067. doi:10.1016/j.brainres.2013.03.039

Heinsbroek, R. P., van Oyen, H. G., \& van de Poll, N. E. (1984). The pituitary-adrenocortical system is not involved in the sex difference in passive avoidance. Pharmacology Biochemistry and Behavior, 20, 663-668.

Hendley, E. D., Atwater, D. G., Myers, M. M., \& Whitehorn, D. (1983). Dissociation of genetic hyperactivity and hypertension in SHR. Hypertension, 5(2), 211-217. doi:10.1161/01. HYP.5.2.211

Hendley, E. D., \& Ohlsson, W. G. (1991). Two ney inbred rat strains derived from SHR: WKHA, hyperactive, and WKHT, hypertensive, rats. American Journal of Physiology, 261(2, Pt. 2), H583-H589.

Holmes, A., Heilig, M., Rupniak, N. M., Steckler, T., \& Griebel, G. (2003). Neuropeptide systems as novel therapeutic targets for depression and anxiety disorders. Trends in Pharmacologi- cal Sciences, 24(11), 580-588. doi:10.1016/j. tips.2003.09.011

Johnston, A. L., \& File, S. E. (1991). Sex differences in animal tests of anxiety. Physiology and Behavior, 49, 245-250.

Kudo, K., Qiao, C. X., Kanba, S., \& Arita, J. (2004). A selective increase in phosphorylation of cyclic AMP response element-binding protein in hippocampal CA1 region of male, but not female, rats following contextual fear and passive avoidance conditioning. Brain Research, 1024(1-2), 233-243. doi:10.1016/j. brainres.2004.08.007

Landgraf, R., \& Wigger, A. (2002). High vs. low anxiety-related behavior rats: An animal model of extremes in trait anxiety. Behavior Genetics, 32(5), 301-314. doi:10.1023/A:1020258104318

Lapin, I. P. (1995). Only controls: Effect of handling, sham injection, and intraperitoneal injection of saline on behavior of mice in an elevated plusmaze. Journal of Pharmacological and Toxicological Methods, 34(2), 73-77.

León, L. G., Brandão, M. L., Franci, C. R., Cardenas, F. P., \& Landeira-Fernandez, J. (2013). Corticosterone plasma concentration in the Carioca high-and low-conditioned freezing rats. Avances en Psicologia Latinoamericana, 31(1), 284-292.

Liebsch, G., Montkowski, A., Holsboer, F., \& Landgraf, R. (1998). Behavioural profiles of two Wistar rat lines selectively bred for high or low anxiety-related behavior. Behavioural Brain Research, 94(2), 301-310. doi:10.1016/S01664328(97)00198-8

Luyten, L., Vansteenwegen, D., van Kuyck, K., Gabriëls, L., \& Nuttin, B. (2011). Contextual conditioning in rats as an animal model for generalized anxiety disorder. Cognitive, Affectective, and Behavioral Neuroscience, 11(2), 228-244. doi:10.3758/s13415-011-0021-6

Lyonfields, J. D., Borkovec, T. D., \& Thayer, J. F. (1995). Vagal tone in generalized anxiety disorder and the effects of aversive imagery and worrisome thinking. Behavior Therapy, 26(3), 457-466. doi:10.1016/S0005-7894(05)80094-2

Marcondes, F. K., Miguel, K. J., Melo, L. L., \& Spadari-Bratfisch, R. C. (2001). Estrous cycle influences the response of female rats in the elevated plus-maze test. Physiology and Behavior, 74(4-5), 435-440. doi:10.1016/S00319384(01)00593-5 
Maren, S., De Oca, B., \& Fanselow, M. S. (1994). Sex differences in hippocampal long-term potentiation (LTP) and Pavlovian fear conditioning in rats: Positive correlation between LTP and contextual learning. Brain Research, 661(1-2), 25-34.

Merikangas, K. R., Zhang, H., Avenevoli, S., Acharyya, S., Neuenschwander, M., \& Angst, J. (2003). Longitudinal trajectories of depression and anxiety in a prospective community study: The Zurich Cohort Study. Archives of General Psychiatry, 60(10), 993-1000. doi:10.1001/archpsyc.60.9.993

Nikiforuk, A., Kos, T., \& Wesołowska, A. (2011). The 5-HT6 receptor agonist EMD 386088 produces antidepressant and anxiolytic effects in rats after intrahippocampal administration. Psychopharmacology (Berl), 217(3), 411-418. doi:10.1007/s00213-011-2297-1

Nomikos, G. G., \& Spyraki, C. (1988). Influence of oestrogen on spontaneous and diazepaminduced exploration of rats in an elevated plus maze. Neuropharmacology, 27(7), 691-696. doi:10.1016/0028-3908(88)90077-9

Overstreet, D. H., Pucilowski, O., Rezvani, A. H., \& Janowsky, D. S. (1995). Administration of antidepressants, diazepam and psychomotor stimulants further confirms the utility of Finders Sensitive Line rats as an animal model of depression. Psychopharmacology (Berl), 121(1), 27-37.

Overstreet, D. H., \& Russell, R. W. (1982). Selective breeding for diisopropyl fluorophosphatesensitivity: Behavioural effects of cholinergic agonists and antagonists. Psychopharmacology (Berl), 78(2), 150-155.

Pellow, S., Johnston, A. L., \& File, S. E. (1987). Selective agonists and antagonists for 5-hydroxytriptamine receptor subtypes, and interactions with yohimbine and FG 7142 using the elevated plus-maze test in rats. Journal of Pharmacy and Pharmacology, 39(11), 917-928.

Phillips, R. G., \& LeDoux, J. E. (1994). Lesions of the dorsal hippocampal formation interfere with background but not foreground contextual fear conditioning. Learning \& Memory, 1(1), 34-44. doi:10.1101/lm.1.1.34

Ponder, C. A., Kliethermes, C. L., Drew, M. R., Muller, J., Das, K., Risbrough, V. B., ...Palmer, A. A. (2007). Selection for contextual fear con- ditioning affects anxiety-like behaviors and gene expression. Genes, Brain and Behavior, 6(8), 736-749.

Porsolt, R. D., Bertin, A., \& Jalfre, M. (1978). "Behavioural despair" in rats and mice: Strain differences and the effects of imipramine. European Journal of Pharmacology, 51, 291-294.

Porsolt, R. M., Le Pichon, M., \& Jalfre, M. (1977). Depression: A new animal model sensitive to antidepressant treatments. Nature, 266, 730732. doi:10.1038/266730a0

Pryce, C. R., Lehmann, J., \& Feldon, J. (1999). Effect of sex on fear conditioning is similar for context and discrete CS in Wistar Lewis and Fischer rat strains. Pharmacology Biochemistry and Behavior, 64(4), 753-759. doi:10.1016/S00913057(99)00147-1

Radcliffe, R. A., Lowe, M. V., \& Wehner, J. M. (2000). Confirmation of contextual fear conditioning QTLs by short-term selection. Behavior Genetics, 30(3), 183-191.

Ramos, A., Berton, O., Mormede, P., \& Chaouloff, F. (1997). A multiple-test study of anxiety-related behaviors in six inbred rat strains. Behavioural Brain Research, 85(1), 57-69. doi:10.1016/ S0166-4328(96)00164-7

Ramos, A., Correia, E. C., Izidio, G. S., \& Bruske, G. R. (2003). Genetic selection of two new rat lines displaying different levels of anxiety-related behaviors. Behavior Genetics, 33(6), 657-668.

Ramos, A., Mellerin, Y., Mormède, P., \& Chaouloff, F. (1998). A genetic and multifactorial analysis of anxiety-related behaviours in Lewis and SHR intercrosses. Behavioural Brain Research, 96(1-2), 195-205. doi:10.1016/S01664328(98)00023-0

Rauch, S. L., Shin, L. M., \& Phelps, E. A. (2006). Neurocircuitry models of posttraumatic stress disorder and extinction: Human neuroimaging research - past, present, and future. Biological Psychiatry, 60(4), 376-382.

Rodgers, R. J., \& Cole, J. C. (1993). Influence of social isolation, gender, strain, and prior novelty on plus-maze behaviour in mice. Physiology and Behavior, 54, 729-736.

Rudy, J. W., Huff, N. C., \& Matus-Amat, P. (2004). Understanding contextual fear conditioning: Insights from a two-process model. Neuroscience and Biobehavioral Reviews, 28(7), 675-685. doi:10.1016/j.neubiorev.2004.09.004 
Sartori, S. B., Hauschild, M., Bunck, M., Gaburro, S., Landgraf, R., \& Singewald, N. (2011). Enhanced fear expression in a psychopathological mouse model of trait anxiety: Pharmacological interventions. PLoS One, 6(2), E16849. doi:10.1371/ journal.pone.0016849

Sartori, S. B., Landgraf, R., \& Singewald, M. (2011). The clinical implications of mouse models of enhanced anxiety. Future Neurology, 6(4), 531571.

Schiller, G. D., Daws, L. C., Overstreet, D. H., \& Orbach, J. (1991). Lack of anxiety in an animal model of depression with cholinergic supersensitivity. Brain Research Bulletin, 26(3), 433435.

Schiller, G. D., Pucilowski, O., Wienicke, C., \& Overstreet, D. H. (1992). Immobility-reducing effects of antidepressants in a genetic animal model of depression. Brain Research Bulletin, 28(5), 821-823.

Setem, J., Pinheiro, A. P., Motta, V. A., Morato, S., \& Cruz, A. P. (1999). Ethopharmacological analysis of 5-HT ligands on the rat elevated plus-maze. Pharmacology Biochemistry and Behavior, 62, 515-521.

Silva, R. H., \& Frussa-Filho, R. (2000). The plusmaze discriminative avoidance task: A new model to study memory-anxiety interactions. Effects of chlordiazepoxide and caffeine. Journal of Neuroscience Methods, 102, 117-125.

Silva, R. H., Kameda, S. R., Carvalho, R. C., Rigo, G. S., Costa, K. L., Taricano, I. D., \& Frussa-Filho, R. (2002). Effects of amphetamine on the plusmaze discriminative avoidance task in mice. Psychopahrmacology (Berl), 160, 9-18.

Sokoloff, G., Parker, C. C., Lim, J. E., \& Palmer, A. A. (2011). Anxiety and fear in a cross of C57BL/6J and DBA/2J mice: Mapping overlapping and independent QTL for related traits. Genes, Brain and Behavior, 10(5), 604-614. doi:10.1111/j.1601-183X.2011.00699.x

Steckler, T., Stein, M. B., \& Holmes, A. (2008). Developing novel anxiolytics: Improving preclinical detection and clinical assessment. In R. A. McArthur \& F. Borsini (Eds.), Animal and translational models for CNS drug discovery. New York: Academic Press.
Steenbergen, H. L., Heinsbroek, R. P. W., Van Hest, A., \& Van de Poll, N. E. (1990). Sex-dependent effects of inescapable shock administration on shuttlebox-escape performance and elevated plus-maze behavior. Physiology and Behavior, 48(4), 571-576.

Stock, H., Foradori, C., Ford, K., \& Wilson, M. A. (2000). A lack of tolerance to the anxiolytic effects of diazepam on the plus-maze: Comparison of male and female rats. Psychopharmacology (Berl), 147, 362-370.

Wegener, G., Mathé, A. A., \& Neumann, I. D. (2012). Selectively bred rodents as models of depression and anxiety. In J. F. Cryan \& A. Reif (Eds.), Behavioral neurogenetics (pp. 139-188). Berlin, Germany: Springer Verlag.

Wehner, J. M., Radcliffe, R. A., Rosmann, R. T., Christensen, S. C., Rasmussen, D. L., Fulker, D. W., \& Wiles, M. (1997). Quantitative trait loci analysis of contextual fear conditioning in mice. Nature Genetics, 17, 331-334. doi:10.1038/ ng1197-335

Weiss, J. M., Cierpial, M. A., \& West, C. H. K. (1998). Selective breeding of rats for high and low motor activity in a swim test: Toward a new animal model of depression. Pharmacology Biochemistry and Behavior, 61(1), 49-66. doi:10.1016/S0091-3057(98)00075-6

Wiltgen, B. J., Sanders, M. J., Behne, N. S., \& Fanselow, M. S. (2001). Sex differences, context preexposure, and the immediate shock deficit in Pavlovian context conditioning with mice. Behavioral Neuroscience, 115(1), 26-32. doi:10.1037//0735-7044. II5.1.26

Received: February, 14, 2014

$1^{\text {st }}$ revision: May, 15, 2014

$2^{\text {nd }}$ revision: August, 06, 2014

Accepted: August, 28, 2014 